Old Dominion University

ODU Digital Commons

\title{
Digging Into Selection Criteria for Accelerator Acceptance: What Kind of Owners Are More Attractive?
}

\author{
Veronika Ermilina \\ Old Dominion University, vermi001@odu.edu \\ Matthew Farrell \\ Old Dominion University, mfarrell@odu.edu \\ Fatemeh Askarzadeh \\ Old Dominion University, faska002@odu.edu
}

Follow this and additional works at: https://digitalcommons.odu.edu/management_fac_pubs

Part of the Business Administration, Management, and Operations Commons, Entrepreneurial and Small Business Operations Commons, Finance and Financial Management Commons, and the Vocational Education Commons

\section{Original Publication Citation}

Ermilina, V., Farrell, M., \& Askarzadeh, F. (2021). Digging into selection criteria for accelerator acceptance: What kind of owners are more attractive? Academy of Management Proceedings, 2021(1), 1-27, Article 14274. https://doi.org/10.5465/AMBPP.2021.14274abstract

This Conference Paper is brought to you for free and open access by the Department of Management at ODU Digital Commons. It has been accepted for inclusion in Management Faculty Publications by an authorized administrator of ODU Digital Commons. For more information, please contact digitalcommons@odu.edu. 


\title{
Digging Into Selection Criteria For Accelerator Acceptance:
}

\section{What Kind of Business Owners Are More Attractive?}

\begin{abstract}
Drawing on signaling theory, we aid in the identification of the rarely acknowledged impact of business owner's features on acceptance to accelerator programs. Using a multi-national sample of 10,298 observations for startups in 166 countries over 2016-2018, we show that accelerators do not evaluate applicants uniformly. We find that entrepreneurs from developing countries are less likely to be accepted by accelerators than entrepreneurs from developed economies. Counterintuitively, we also find an advantage for female entrepreneurs in accelerator acceptance. Further, our results suggest a positive impact of education. Accelerators are a growing provider of entrepreneurial resources and a main driver of growth and innovativeness. Despite the extant literature demonstrating the benefits of accelerators, determinants of acceptance to these programs, particularly at the individual level, are underexplored. Here, we extend entrepreneurship literature and show some sources of variation in access to international accelerator programs. Our comparative study enhances business owners' insight for application to entrepreneurial resources.
\end{abstract}

Keywords Accelerator acceptance; Developed vs developing; International entrepreneurship; Signaling theory; Gender; Education 


\section{Introduction}

Entrepreneurship is a widely known catalyst of changes in the economy and a key driver of economic growth. While new ventures contribute to national income and employment rates, many of them suffer from a lack of access to external services, particularly in developing economies (Beck, Demirgüç-Kunt, and Maksimovic, 2008; Ratten, Ferreir, and Fernandes, 2016). Therefore, access to global initiatives that support growth-oriented entrepreneurs is highly valuable for ventures and international entrepreneurs. Entrepreneurial incubation programs have attracted more attention from scholars and practitioners in the last decade (e.g., Crișan, Salanță, Beleiu, Bordean, and Bunduchi 2019). Particularly, scholars have been interested in the subset of incubators known as accelerators, which have a stronger focus on growing a nascent firm (Bosma and Stam, 2012). The number of accelerators in the USA has increased from 1 in 2005 to 578 in 2016 (Small Business Trends, 2016), attesting to the mounting importance of this recent addition to assistantship programs.

Accelerator programs, defined as, "fixed-term, cohort-based program, including mentorship and educational components that culminate in a public pitch-event or demo-day" (Cohen and Hochberg, 2014, p. 4), provide many benefits to new ventures. Particularly, prior studies suggest accelerators may improve firm performance (Eisenhardt and Schoonhoven, 1990; Ensley, Carland, and Carland, 1998; Shrader and Siegel, 2007) and provide newer firms with an office space, financial resources, physical resources, and access to networks (Carayannis and Von Zedtwitz, 2005; Cohen and Hochberg, 2014; Plummer, Allison, and Connelly, 2016; Roberts and Lall, 2019). Bearse (1998) noted that an incubatee survival rate is about 80 percent, well above typical levels observed among fledgling firms that were not enrolled in such programs. Similarly, 
Smilor (1987) found that acceptance into incubation programs gave firms structure, credibility, and offered administrative support.

Despite strong empirical and theoretical arguments for the desirability of accelerator acceptance, little research has been performed regarding the factors that lead to admission into an accelerator program for nascent firms. Individual-level features of business owners from multiple countries can create biases toward the desirability of their ventures, but such variables remain underexplored in accelerator acceptance literature. Using signaling theory (Certo, 2003; Connelly, Certo, Ireland, and Reutzel, 2011; Spence, 1978), we seek to understand how some of the salient and observable features of business owners, including their country of birth, gender, and education, can influence their chances of acceptance into such programs. Due to a high application volume from all over the world (Cohen, 2013), accelerator programs accept only a very small percentage of ventures (Cohen, 2013). High competition among ventures results in a complicated selection process in which accelerators use observable features (i.e., signals) (Spence, 2002) to screen applicants. As such, it is imperative for business owners to send signals that effectively present the quality of their ventures. By examining signals that are effective in gleaning accelerator acceptance, we would be able to explain variation in acceptance into these programs for entrepreneurs from multiple countries.

We examine several factors, including a lead founder's country of birth, gender, and an educational level. Since accelerators usually rely on external team "signals" (i.e., indicators of a firm's capabilities), a selection process may be challenging due to a lack of sufficient information (Cohen, 2013). Accelerators prefer face-to-face physical or online interviews with a founding team (Pauwels, Clarysse, Wright, and Van Hove, 2016), often represented by a lead founder. As such, we mainly focus on lead founders and signals that their team might send to evaluators. Country of 
birth affects founders' values, cognitive schema, demeanor, and language (Hambrick, Davison, Snell, and Snow, 1998). Education is a known and significant contributor to firm's performance (Hambrick, Cho, and Chen, 1996) and innovation (Bantel and Jackson, 1989). We also focus on gender which is a traditional source of bias in interpreting individual behaviors and abilities (Alsos and Ljunggren, 2017; Gupta, Turban, Wasti, and Siktar, 2009; Harrison and Mason, 2007).

We argue that ventures will be considered more favorably and more likely to be accepted by accelerators when their lead founder is from a developed country. On the contrary, ventures will be less likely to be accepted when a lead founder is from a developing country. We also predict that, compared to men, female lead founders have a higher chance of being accepted. Additionally, we hypothesize that educational level has a positive impact on accelerator acceptance. Using a sample of 203 accelerators and 10,298 observations for 2324 startups in 166 countries over 2016-2018, we test our hypotheses and find support for our arguments. Figure 1 indicates the acceptance to accelerator programs for founders from different continents and provides information for the comparative purposes in our global sample.

Insert Figure 1 about here

Our paper offers several contributions. First, through the interplay of signaling theory and international entrepreneurship assistantship literature, we highlight the individual aspects of startups in access to accelerator programs. By doing so, we extend the growing research on antecedents of acceptance to accelerators (Yang, Kher, and Newbert, 2020) and directly respond to calls for a more nuanced examination of evaluation by entrepreneurship resource providers (Shepherd, Williams, and Patzel, 2015), specifically by accelerators (Drover, Busenitz, Matusik, 
Townsend, Anglind, and Dushnitsky, 2017). Second, examination of the impact of a lead founder's country of birth (i.e., international versus domestic) offers promising research directions for scholars in international entrepreneurship. Moreover, this study adds to our knowledge of comparative research on entrepreneurs' features for a global investigation of accelerator acceptance. Particularly, we show continents from which founders have a highest chance of acceptance to accelerators. Finally, by uncovering features leading to accelerator's acceptance, we desire to offer practical suggestions for entrepreneurs to improve their chance of being selected by accelerators, a milestone achievement for resource-constrained new ventures.

\section{Theoretical background and hypotheses development}

\subsection{Venture selection and incubator acceptance}

Previous literature heavily focused on entrepreneurs' features, such as education and gender and their impact on firms' financial performance (Cooper, Gimeno-Gaskon, and Woo, 1994; Cassar, 2014). We extend this literature by discussing the impact of these features on accelerator's acceptance. Particularly, we study how founders' country of birth, gender, and educational level may impact an accelerator's acceptance. We focus on lead founders because accelerators often interview them (Gonzales-Uribe and Leatherbee, 2017) while going through a very competitive selection process from a large and diverse pool of applicants.

Literature highlights the importance of accelerators by noting that "without the incubator, most of the entrepreneurs would either not be in business or struggle to remain in business" (Plosila and Allen, 1985, p. 22). Furthermore, scholars argue that incubators provide ventures with various benefits, including below-market office space rent, mutual incubatee assistance and/or purchasing 
agreements, business consulting services, and technological and networking assistance (Allen and Rahman, 1985; Lumpkin and Ireland, 1988; Temali and Campbell, 1984).

Here, we focus on a specific type of incubators - accelerators, which are different from other types of incubators as they are typically shorter in time and focus on scaling up as opposed to starting up new ventures (Cohen, 2013). Accelerators can be described by the following characteristics: their programs usually last around three months; they buy ventures' equity in return for accelerating firms; they usually help competitive ventures at an early stage; they offer seminars and mentorship; and they often have a designated location (Cohen, 2013). Often, accelerators' applicants are driven by a higher growth and return on investment (ROI) (Isabelle, 2013) which become one of the primary areas of interest for evaluators (Bosma and Stam, 2012). Accepted applicants often enjoy a higher survival rates after accelerators' programs (Isabelle, 2013) and accelerators get a firm's share to get a faster return on investment (Isabelle, 2013) by aligning interests of investors and ventures. Therefore, it is imperative to understand what accelerators' requirements are and how to best fit accelerators' expectations (Isabelle, 2013).

\subsection{Signaling theory}

We apply signaling theory to this study because of our focus on information asymmetries; in our study, accelerators lack sufficient information about ventures (Connelly et al., 2011). The focus of signaling theory is to reduce the information asymmetry between two parties (Spence, 2002). We have two parties, represented by a new venture, accelerator's applicant, which applies into a program by sending some information (i.e., signals) about its current capabilities (Filatotchev and Bishop, 2002), and an accelerator that receives that information (i.e., signals) from a new venture. Such information is necessary to reduce the information asymmetry between two parties and sending right signals may be viewed as a part of a firm's strategy (Connelly et al., 2011). 


\subsection{Country of birth and accelerator acceptance}

Several large public companies, such Intel, eBay, Yahoo!, or Google, had at least one foreign founder (Achidi, Ndofor, and Priem, 2011). However, these large companies with foreign founders are not the only ones that provide economic benefits to the market. There are many small firms with foreign founders that stimulate economic growth. According to various studies on cultural diversity (Hambrick et al., 1998; Hofstede, 1984), ethnicity or country of birth affects an individual in various ways, including how an individual perceives teamwork, views relationships with those higher in a rank, and chooses to communicate with subordinates. To help understand how cultural differences affect managerial techniques and philosophies, Hofstede (1984) proposed several cultural dimensions - individualism versus collectivism, large versus small power distance, strong versus weak uncertainty avoidance, and masculinity versus femininity. Some individuals, despite being born in a specific country, may not be true representatives of that country (Hambrick et al., 1998). However, the country of birth is a signal that can impact interpretations about individual behavior.

Stakeholders, particularly investors, pay close attention to where a founding team, including a lead founder, comes from (Chaganti et al., 2008; Ndofor and Priem, 2011; Saxenian, 2002). Often, entrepreneurship in a foreign country entails negative consequences since foreign entrepreneurs lack country-specific knowledge - language, traditions, and culture (Aliaga-Isla and Rialp, 2013; Teixeira et al., 2007). Many studies have been done on managers' country of birth and its impact on a firm's financial performance. Chaganti et al. (2008) examined ethnic immigrant versus non-ethnic non-immigrant teams in new internet ventures and found that ethnic-immigrant teams were more aggressive. Similarly, Chand and Ghorbani (2011) found that country of birth 
had an impact on firm performance when studying social networks, particularly how founders formed their connections.

Developed countries are often associated with functional laws, and are overall perceived to be more trustworthy. On the other hand, developing countries are subject to more scrutiny due to an often corrupt environment and non-transparent ways of conducting business (CuervoCazurra, 2006). Due to information asymmetry, there is always room for "cheating". That is, one party can send incomplete or even false information (Connelly et al., 2011). This concern can be alleviated when there is more transparency and regulation. Additionally, ventures coming from developing countries find it harder to establish their legitimacy because stakeholders initially take time to establish trust with such organizations (Ahlstrom et al., 2008). Moreover, many of the accelerator programs are located in developed countries and it is likely that they perceive less information asymmetry and more similarity in their interactions with applicants from developed countries. Building on extant research, we posit that entrepreneurs originating from a developed country will signal superior environmental/organizational fit, networking capability, and resource acquisition capability relative to those who are not, ceteris paribus.

H1. New ventures with a lead founder from a developed country are more likely to be accepted by accelerators.

\subsection{Gender and accelerator acceptance}

Most of the previous studies suggest that women may experience prejudice when attempting to gain access to resources, particularly financial capital (e.g., Alsos \& Ljunggren, 2017; Gupta et al., 2009). Many contexts such as debt, business angel, and venture capital financing confirm this disadvantage (e.g., Harrison \& Mason, 2007). However, some recent studies show that for 
crowdfunding, women are more likely to access resources compared to their male counterparts (Powell \& Eddleston, 2013). Accelerator programs are specifically seeking to support promising groups that are not easily identified and supported by others.

Female entrepreneurs form a novel and favorable market for capital providers (Carter et al., 2007). Due to the reformed gender perception in society in recent years, more investors have recognized women's competency in the business world. These changes along with the record of many successful female entrepreneurs have started to modify traditional gender biases (Rocha, \& Van Praag, 2020). Opposed to previous studies that argue female-led ventures have lower performance than male-led ventures (Du Rietz \& Henrekson, 2000), a growing number of studies suggest no significant difference between these ventures (Jennings \& Brush, 2013; Rocha \& Van Praag, 2020) or even an advantage for female-led firms (e.g. Robb \& Watson, 2012). Due to historical barriers for women in attaining entrepreneurial resources (e.g., Marlow \& Patton, 2005), women who run businesses are the survivors of discriminatory processes and tend to be remarkably competent (Eagly \& Carli, 2003). In addition to high competency, women are also perceived to be more trustworthy (Eckes, 2002; Maddux \& Brewer, 2005). Because of the information asymmetry between partners (Maxwell \& Lévesque, 2014), entrepreneurs' behavioral intentions constitute a key factor for investment decisions and trust plays a critical role (Warnick et al., 2018). The high trustworthiness of women as well as their competence make them appealing for accelerators.

Moreover, supporting underrepresented groups can bring legitimacy for accelerators in the external environment (Certo, 2003) and help them in building reputations over time. In addition to positive financial returns, accelerators aim to generate social and/or environmental impact (Lall et al., 2013). Research supports the idea that women are more likely to engage in corporate social responsibility (e.g., Setó-Pamies, 2015), which makes women a good fit for accelerators, which 
usually seek to contribute to society. In sum, since accelerators focus mainly on empowering capable business owners whose potentials are not evident to others, we expect female advantage in access to accelerator programs.

H2. New ventures with a female lead founder are more likely to be accepted by accelerators.

\subsection{Education and accelerator acceptance}

Studies suggested that the educational level in founding teams led to increased innovativeness and improved financial performance (Delmar and Davidsson, 2000; Robinson and Sexton, 1994). Signaling theory is primarily focused on sending deliberate and positive information to a receiver to demonstrate its positive attributes (Connelly et al., 2011). The level of education is associated with many positive characteristics, including the greater propensity of action, competitive behaviors, and greater financial performance (Hambrick et al., 1996), greater capital raised during an IPO (Zimmerman, 2008), and innovation (Bantel and Jackson, 1989). Moreover, successful founders are good at recognizing an opportunity (Hofer and Sandberg, 1987) and executing it for

fruitful financial performance (Chandler and Jansen, 1992). Recognizing an opportunity itself requires competence (Chandler and Jansen, 1992; Pavett and Lau, 1983). To be competent in a technical-functional role founders must know how to use tools and how to operate processes (Chandler and Jansen, 1992; Pavett and Lau, 1983). A higher level of education provides all these types of competence and teaches how to use tools in the technical-functional role (Baum and Payea, 2004).

"Participating in an accelerator program may not necessarily keep the venture (or the venture idea) alive; instead, it may speed up the cycle of the venture - leading to quicker growth" (Cohen, 2013, p.21). That is, given the often-short duration of an accelerator program - usually three months (Cohen, 2013), accelerators should choose wisely and pick those ventures that can 
benefit the most out of such a short program. Founders with higher university training compared to those without this documented record of knowledge would probably be more appealing to accelerators because knowledge signals the ability to generate profit. Therefore, it is plausible to consider that a higher educational level of founders will lead to accelerator's acceptance.

H3. New ventures with more educated founders are more likely to be accepted by accelerators.

\section{Research design}

\subsection{Sample and data}

Our dataset consists of a sample of 2324 international and domestic firms, which applied for accelerators between 2013 and 2018. This survey-based data is extracted from the Entrepreneurship Database Program (EDP). Data were collected first when entrepreneurs applied to the accelerator and follow-ups were conducted on an annual basis. Since 2016 was the first year that data on acceptance was collected, our final sample is limited to 2016 - 2018. After dealing with missing values, we were left with 10,298 observations, which were Winsorized at the 1 and 99 percentile levels to reduce the effect of outliers.

\subsection{Variables}

Dependent Variable: Acceptance was coded as a dichotomous variable with "1" being assigned to firms that were accepted and "0" to firms that applied but were not accepted.

Independent Variables: According to the ANDE Annual Report (2018) the first founder listed should be considered the lead founder of the venture. Country of origin was operationalized by the level of development of the country that the lead founder came from. We used the natural logarithm of Gross Domestic Product (GDP) Per Capita as a proxy for country development. Gender was operationalized by a dichotomous variable with "1" assigned to women and "0" to 
men. For Education, we used the highest level of education attained, with options including none, primary school, middle school, high school, technical/vocational school, associate's degree, bachelor's/honor's degree, master's degree, and Ph.D., we operationalized this as an ordinal scale with values from " 0 " to " 8 " representing each of the levels in the dataset. These values were then summed across the top members of the founding team, yielding the team education variable.

Control Variables: We controlled for the following variables. For Legal Status, which has the potential to impact strategy, structure, and policies (O'Connor \& Raber, 2001), we used dummies that show the status of the venture, including nonprofit, for-profit, and "undecided/other" being the reference group. For Sector, we included four dummy variables to control for the economic sector of the startup, including health, information technology, and agriculture, with "other" serving as the reference group. For Financial Goals, since firm owner expectations of growth has been reported to have a positive relationship with actual firm growth (Wiklund \& Shepherd, 2003), we assigned a value of " 1 " to firms that wished to generate profits rather than merely cover their costs, and "0" otherwise. For Social Motive, as entrepreneurs' motivation to achieve their visions would increase when that vision was more specific (Baum and Locke, 2004), we coded this variable as "1" for firms that expressed a specific social motive and "0" otherwise. For Patents, as it shows the innovativeness capabilities (e.g., Baum et al., 2000), we coded this variable as a "1" if the firm held any patents and "0" otherwise. For Founder Age, we used the log of the lead entrepreneur's age to eliminate skewness. For Entrepreneurial Experience as an important factor (Hsu, 2007), we operationalized it as the sum of the total number of ventures that the founding team had started, including government and nonprofit as well as for-profit entities. For Impact Area we controlled for the social impact goals by including dummies for agricultural products, access to water, and community development, with "other" being the reference category. 
Managerial Experience was coded " 1 " if the founder indicated any managerial experience in the survey and "0" otherwise. For Social Signals, which can show legitimacy (Yang et al., 2020), we coded this dummy variable as "1" for firms that had received investments from sources such as crowdfunding, government, fellowship programs, business plan competitions, foundations, or other nonprofit groups, and other companies, and "0" otherwise. For Economic Signals and Self Funding in Past Year, we coded the venture as " 1 " if it had received funding from an outside source (economic signals) or a founder (self funding). For Profitability, we used options ranging from negative to ranges from 0 to 5 percent, 6 to 10 percent, 11 to 15 percent, 16 to 20 percent, or more than 20 percent. We operationalized this as an ordinal scale, with "1" representing negative profitability, and up to "6" constitute more than 20 percent.

\section{Results}

Given that our dependent variable, Selected, is binary, we employed logit regressions to test our hypotheses. We used robust standard errors. Table 1 shows the descriptive analysis of the variables and their correlations. The correlation between accelerator acceptance with the country of birth, gender, and education is $.03, .05$ and .02 , respectively. Each variable was tested for multicollinearity. Their variance inflation factors were all well below the recommended threshold of 5, suggesting no multicollinearity concern.

Insert Table 1 about here

The results of the hypotheses tests are shown in Table 2. Model 1 contains all of our control variables. Interestingly, we found that the impact of lead founder's age on accelerator acceptance is positive, as one might expect, but insignificant. Further, the results also indicate that the impact 
of the lead founder's experience on acceptance is negative on both a managerial and entrepreneurial level. As we lack data regarding the performance of their prior ventures, we are unable to exclude the possibility of adverse selection in terms of failed entrepreneurs applying for accelerator programs.

Model 2 includes all control variables plus the extent of development for the lead founder's country of birth. The significant and positive coefficient of the country of origin $(\beta=.11, p<.01)$ supports Hypothesis 1, which predicted that firms with a lead founder from a more developed country would be more likely to be accepted. In Model 3, we examine the impact of gender. The significant and positive coefficient of gender $(\beta=.27, \mathrm{p}<.01)$ supports Hypothesis 2 . Consistent with this result, we conclude that a female lead founder has a higher chance of acceptance. Model 4 examines our control variables with the addition of the founder team's education. The model ( $\beta$ $=.01, \mathrm{p}<.05)$ suggests that higher education of the founding team led to increased chances of being accepted by accelerators, supporting Hypothesis 3 . Model 5 included all control variables plus all independent variables.

Insert Table 2 about here

\section{Discussion}

Access to resources is a main reason for the growth of small ventures, particularly in developing economies (Bongomin et al., 2017). Accelerators programs are new addition to the cadre of entrepreneurship assistantship services, which are open to international applicants. In this paper, we examined the influential factors on accelerators' acceptance of entrepreneurial founding teams. 
Specifically, we studied the impacts of entrepreneurial features of founders including country of birth, gender, and education. We found that if a lead founder is from a developed country, such a venture will be more likely to be accepted by an accelerator, and less likely if a lead founder is from a developing country. Additionally and interestingly, we observed female business owners have a higher chance of acceptance than their male counterparts. Finally, yet importantly, we found that the founder team's educational level has a positive impact on accelerator acceptance. Our results were surprising in a variety of respects and have noteworthy implications for practitioners as well as applications of signaling theory.

By bringing insights from signaling theory into the international entrepreneurship assistantship literature, we provided unique findings for the criteria that accelerators use for new venture selection. While the majority of literature mainly focuses on the outcome of accelerator acceptance, such as increased performance and innovativeness, much is left unknown for antecedents. We directly respond to the call for research on the criteria that might explain variation in accelerator acceptance (Drover et al., 2017). While some research examines the criteria at the venture level (e.g., Yang et al., 2020), the direct impact of individual-level factors is underexplored. We found that country of origin, while may not be a true representative of the individual's skills and behavior, can be a source of bias. We found that education even irrelevant to entrepreneurship can have a positive impact on acceptance.

We also extend female entrepreneurship literature by exploring the gender effect in the accelerator context. This is the first study that supports female advantage in the emerging context of accelerators, which is unique to the literature. Women's participation in entrepreneurship is vital for economic growth (Brush et al., 2004) as they are the fastest-growing sector of new venture ownership in the US (Becker-Blease \& Sohl, 2007). We extend the recent findings that suggest 
women's high likelihood of access to non-traditional resources such as crowdfunding (Greenberg and Mollick, 2017) and support this advantage in the context of accelerators.

Our results would be helpful for policymakers and business owners, particularly female entrepreneurs by providing insights into the underlying reasons that might account for variation in access to non-traditional resources. Despite the numerous benefits of startups for the economy, there is a predominant gap in an assistantship, which forces new ventures to turn to non-traditional resources such as accelerator programs to fill the void (Radojevich-Kelley \& Hoffman, 2012). Consequently, it is a vital practical matter for startup owners to get familiar with the factors that impact accelerator acceptance. CEOs such as Elon Musk and Jeff Bezos have increasingly been the subject of media attention and academic literature (e.g., Koh, 2011). Given our results, young firms that aspire to accelerator acceptance may wish to "sell" their image with a well-educated lead founder who comes from a developed nation. Since accelerators are global resources open to international applicants, our study has practical implications for international entrepreneurs and policymakers by showing the impact that the development level of countries in access to international resources that assist entrepreneurial development. Governments are a key part of economic development (Galvão et al., 2017) and their informed decisions can enhance national prosperity. Having women also seems to be a helpful signal to increase the chance of acceptance. This is also important for policymakers who wish to improve gender equality and reform national settings.

\section{Limitations}

One important limitation of our study is that there is no data about the features of judges in the accelerator programs. Their individual aspects including country of origin, gender, and education have the potential to change the impact of these criteria on accelerator acceptance. Another 
limitation is the lack of data about accelerators. Unfortunately, the ANDE database does not have any information on the accelerators themselves, and the countries in which they are located. 


\section{References}

Achidi Ndofor, H., \& Priem, R. L. (2011). Immigrant entrepreneurs, the ethnic enclave strategy, and venture performance. Journal of Management, 37(3), 790-818.

Ahlstrom, D., Bruton, G. D., \& Yeh, K. S. (2008). Private firms in China: Building legitimacy in an emerging economy. Journal of World Business, 43(4), 385-399.

Aliaga-Isla, R., \& Rialp, A. (2013). Systematic review of immigrant entrepreneurship literature: previous findings and ways forward. Entrepreneurship and Regional Development, 25(9-10), 819-844.

Allen, D. N., \& Rahman, S. (1985). Small business incubators: a positive environment for entrepreneurship. Journal of Small Business Management (pre-1986), 23(000003), 12.

ANDE Annual Report (2018). The Entrepreneurship Database Program 2017 Data Summary. Aspen Network of Development Entrepreneurs.

Alsos, G. A., \& Ljunggren, E. (2017). The role of gender in entrepreneur-investor relationships: A signaling theory approach. Entrepreneurship Theory and Practice, 41(4), 567-590.

Bantel, K. A., \& Jackson, S. E. (1989). Top management and innovations in banking: Does the composition of the top team make a difference? Strategic Management Journal, 10(S1),107-124.

Baum, J. A., Calabrese, T., \& Silverman, B. S. (2000). Don't go it alone: Alliance network composition and startups' performance in Canadian biotechnology. Strategic Management Journal, 21(3), 267 294.

Baum, J. R., \& Locke, E. A. (2004). The relationship of entrepreneurial traits, skill, and motivation to subsequent venture growth. Journal of Applied Psychology, 89(4), 587.

Baum, S., \& Payea, K. (2004). Education pays 2004: The benefits of higher education for individual and society. 
Bearse, P. (1998). A question of evaluation: NBIA's impact assessment of business incubators. Economic Development Quarterly, 12(4), 322-333.

Beck, T., Demirgüç-Kunt, A., \& Maksimovic, V. (2008). Financing patterns around the world: Are small firms different?. Journal of financial economics, 89(3), 467-487.

Becker-Blease, J. R., \& Sohl, J. E. (2007). Do women-owned businesses have equal access to angel capital? Journal of Business Venturing, 22(4), 503-521.

Bongomin, G. O. C., Ntayi, J. M., Munene, J. C., \& Malinga, C. A. (2017). The relationship between access to finance and growth of SMEs in developing economies. Review of International Business and Strategy.

Bosma, N., \& Stam, E. (2012, March). Local policies for high-employment growth enterprises.

In Report prepared for the OECD/DBA international workshop on high-growth firms: local policies and local determinants, Copenhagen.

Brush, C. G., Carter, N. M., Gatewood, E., Greene, P. G., \& Hart, M. M. (2004). Clearing the hurdles: Women building high-growth businesses. London: Financial Times/Prentice Hall.

Carayannis, E. G., \& Von Zedtwitz, M. (2005). Architecting gloCal (global-local), real-virtual incubator networks (G-RVINs) as catalysts and accelerators of entrepreneurship in transitioning and developing economies: lessons learned and best practices from current development and business incubation practices. Technovation, 25(2), 95-110.

Cassar, G. (2014). Industry and startup experience on entrepreneur forecast performance in new firms. Journal of Business Venturing, 29(1), 137-151.

Carter, S., Shaw, E., Lam, W., \& Wilson, F. (2007). Gender, entrepreneurship, and bank lending: The criteria and processes used by bank loan officers in assessing applications. Entrepreneurship Theory and Practice, 31(3), 427-444. 
Certo, S. T. (2003). Influencing initial public offering investors with prestige: Signaling with board structures. Academy of Management Review, 28(3), 432-446.

Chaganti, R. R. S., Watts, A. D., Chaganti, R., \& Zimmerman-Treichel, M. (2008). Ethnicimmigrants in founding teams: Effects on prospector strategy and performance in new Internet ventures. Journal of Business Venturing, 23(1), 113-139.

Chand, M., \& Ghorbani, M. (2011). National culture, networks and ethnic entrepreneurship: A comparison of the Indian and Chinese immigrants in the US. International Business Review, 20(6), 593-606.

Chandler, G. N., \& Jansen, E. (1992). The founder's self-assessed competence and venture performance. Journal of Business Venturing, 7(3), 223-236.

Cohen, S. (2013). What do accelerators do? Insights from incubators and angels. Innovations: Technology, Governance, Globalization, 8(3-4), 19-25.

Cohen, S., \& Hochberg, Y. (2014). Accelerating startups: The seed accelerator phenomenon.

Connelly, B. L., Certo, S. T., Ireland, R. D., \& Reutzel, C. R. (2011). Signaling theory: A review and assessment. Journal of Management, 37(1), 39-67.

Cooper, A. C., Gimeno-Gascon, F. J., \& Woo, C. Y. (1994). Initial human and financial capital as predictors of new venture performance. Journal of Business Venturing, 9(5), 371-395.

Crișan, E. L., Salanţă, I. I., Beleiu, I. N., Bordean, O. N., \& Bunduchi, R. (2019). A systematic literature review on accelerators. The Journal of Technology Transfer, 1-28.

Cuervo-Cazurra, A. (2006). Who cares about corruption? Journal of International Business Studies, 37(6), 807-822.

Delmar, F., \& Davidsson, P. (2000). Where do they come from? Prevalence and characteristics of nascent entrepreneurs. Entrepreneurship and Regional Development, 12(1), 1-23. 
Drover, W., Busenitz, L., Matusik, S., Townsend, D., Anglin, A., \& Dushnitsky, G. (2017). A review and road map of entrepreneurial equity financing research: venture capital, corporate venture capital, angel investment, crowdfunding, and accelerators. Journal of management, 43(6), 1820-1853.

Du Rietz, A., \& Henrekson, M. (2000). Testing the female underperformance hypothesis. Small Business Economics, 14(1), 1-10.

Eagly, A. H., \& Carli, L. L. (2003). The female leadership advantage: An evaluation of the evidence. The Leadership Quarterly, 14(6), 807-834.

Eckes, T. (2002). Paternalistic and envious gender stereotypes: Testing predictions from the stereotype content model. Sex Roles, 47(3-4), 99-114.

Eisenhardt, K. M., \& Schoonhoven, C. B. (1990). Organizational growth: Linking founding team, strategy, environment, and growth among US semiconductor ventures, 1978-1988. Administrative Science Quarterly, 504-529.

Ensley, M. D., Carland, J. W., \& Carland, J. C. (1998). The effect of entrepreneurial team skill heterogeneity and functional diversity on new venture performance. Journal of Business and Entrepreneurship, 10(1), 1.

Filatotchev, I., \& Bishop, K. (2002). Board composition, share ownership, and 'underpricing'of UK IPO firms. Strategic Management Journal, 23(10), 941-955.

Galvão, A., Mascarenhas, C., Rodrigues, R. G., Marques, C. S., \& Leal, C. T. (2017). A quadruple helix model of entrepreneurship, innovation and stages of economic development. Review of International Business and Strategy.

Gonzalez-Uribe, J., \& Leatherbee, M. (2017). The effects of business accelerators on venture performance: Evidence from start-up chile. The Review of Financial Studies, 31(4), 1566-1603. 
Greenberg, J., \& Mollick, E. (2017). Activist choice homophily and the crowdfunding of female founders. Administrative Science Quarterly, 62(2), 341-374.

Gupta, V. K., Turban, D. B., Wasti, S. A., \& Sikdar, A. (2009). The role of gender stereotypes in perceptions of entrepreneurs and intentions to become an entrepreneur. Entrepreneurship Theory and Practice, 33(2), 397-417.

Hambrick, D. C., Cho, T. S., \& Chen, M. J. (1996). The influence of top management team heterogeneity on firms' competitive moves. Administrative Science Quarterly, 659-684.

Hambrick, D. C., Davison, S. C., Snell, S. A., \& Snow, C. C. (1998). When groups consist of multiple nationalities: Towards a new understanding of the implications. Organization Studies, 19(2), 181-205.

Harrison, R. T., \& Mason, C. M. (2007). Does gender matter? Women business angels and the supply of entrepreneurial finance. Entrepreneurship Theory and Practice, 31(3), 445-472.

Hofer, C. W., \& Sandberg, W. R. (1987). Improving new venture performance: Some guidelines for success. American Journal of Small Business, 12(1), 11-26.

Hofstede, G. (1984). Cultural dimensions in management and planning. Asia Pacific Journal of Management, 1(2), 81-99.

Hsu, D. H. (2007). Experienced entrepreneurial founders, organizational capital, and venture capital funding. Research Policy, 36(5), 722-741.

Isabelle, D. A. (2013). Key factors affecting a technology entrepreneur's choice of incubator or accelerator. Technology Innovation Management Review, 3(2).

Jennings, J. E., \& Brush, C. G. (2013). Research on women entrepreneurs: challenges to (and from) the broader entrepreneurship literature? Academy of Management Annals, 7(1), 663-715.

Koh, K. (2011). Value or glamour? An empirical investigation of the effect of celebrity CEOs 
on financial reporting practices and firm performance. Accounting and Finance, 51(2), 517-547.

Lall, S., Bowles, L., \& Baird, R. (2013). Bridging the "Pioneer Gap": The role of accelerators in launching high-impact enterprises. Innovations: Technology, Governance, Globalization, 8(3-4), 105-137.

Lumpkin, J. R., \& Ireland, R. D. (1988). Screening practices of new business incubators: the evaluation of critical success factors. American Journal of Small Business, 12(4), 59-81.

Marlow, S., \& Patton, D. (2005). All credit to men? Entrepreneurship, finance, and gender. Entrepreneurship Theory and Practice, 29(6), 717-735.

Maxwell, A. L., \& Lévesque, M. (2014). Trustworthiness: A critical ingredient for entrepreneurs seeking investors. Entrepreneurship Theory and Practice, 38(5), 1057-1080.

O'Connor, J. \& Raber, R. (2001). The best of both worlds. Association Management, 53(5), 28-36.

Pauwels, C., Clarysse, B., Wright, M., \& Van Hove, J. (2016). Understanding a new generation incubation model: The accelerator. Technovation, 50, 13-24.

Pavett, C. M., \& Lau, A. W. (1983). Managerial work: The influence of hierarchical level and functional specialty. Academy of Management Journal, 26(1), 170-177.

Plosila, W. H., \& Allen, D. N. (1985). Small business incubators and public policy: implications for state and local development strategies. Policy Studies Journal, 13(4), 729-734.

Plummer, L. A., Allison, T. H., \& Connelly, B. L. (2016). Better together? Signaling interactions in new venture pursuit of initial external capital. Academy of Management Journal, 59(5), 1585-1604.

Powell, G. N., \& Eddleston, K. A. (2013). Linking family-to-business enrichment and support to entrepreneurial success: do female and male entrepreneurs experience different outcomes?. Journal of business venturing, 28(2), 261-280.

Radojevich-Kelley, N., \& Hoffman, D. L. (2012). Analysis of accelerator companies: An exploratory case study of their programs, processes, and early results. Small Business Institute Journal, 8(2), 54-70. 
Ratten, V., Ferreira, J., \& Fernandes, C. (2016). Entrepreneurial and network knowledge in emerging economies. Review of International business and Strategy.

Robb, A. M., \& Watson, J. (2012). Gender differences in firm performance: Evidence from new ventures in the United States. Journal of Business Venturing, 27(5), 544-558.

Roberts, P. W., \& Lall, S. A. (2019). A Closer Look at Entrepreneur Selection. In Observing Acceleration (pp. 107-117). Palgrave Macmillan, Cham.

Robinson, P. B., \& Sexton, E. A. (1994). The effect of education and experience on selfemployment success. Journal of Business Venturing, 9(2), 141-156.

Rocha, V., \& Van Praag, M. (2020). Mind the gap: The role of gender in entrepreneurial career choice and social influence by founders. Strategic Management Journal, 41(5), 841-866.

Saxenian, A. (2002). Silicon Valley's new immigrant high-growth entrepreneurs. Economic Development Quarterly, 16(1), 20-31.

Setó-Pamies, D. (2015). The relationship between women directors and corporate social responsibility. Corporate Social Responsibility and Environmental Management, 22(6), 334-345.

Shepherd, D. A., Williams, T. A., \& Patzelt, H. (2015). Thinking about entrepreneurial decision making: Review and research agenda. Journal of Management, 41(1), 11-46.

Shrader, R., \& Siegel, D. S. (2007). Assessing the Relationship between Human Capital and

Firm Performance: Evidence from Technology-Based New Ventures. Entrepreneurship Theory and Practice, 31(6), 893-908.

Small Business Trends (2016). "What is a Business Accelerator - And How Does it Differ from an Incubator?". Retrieved from https://smallbiztrends.com/2016/08/business-accelerator-differincubator.html 
Smilor, R. W. (1987). Managing the incubator system: critical success factors to accelerate new company development. IEEE Transactions on Engineering Management, (3), 146-155.

Spence, M. (1978). Job market signaling. In Uncertainty in Economics (pp. 281-306).

Spence, M. (2002). Signaling in retrospect and the informational structure of markets. American Economic Review, 92(3), 434-459.

Teixeira, C., Lo, L., \& Truelove, M. (2007). Immigrant entrepreneurship, institutional discrimination, and implications for public policy: a case study in Toronto. Environment and Planning C: Government and Policy, 25(2), 176-193.

Temali, M., \& Campbell, C. (1984). Business incubator profiles: a national survey. Hubert H. Humphrey Institute.

Warnick, B. J., Murnieks, C. Y., McMullen, J. S., \& Brooks, W. T. (2018). Passion for entrepreneurship or passion for the product? A conjoint analysis of angel and VC decision-making. Journal of Business Venturing, 33(3), 315-332.

Wiklund, J., \& Shepherd, D. (2003). Aspiring for and achieving growth: The moderating role of resources and opportunities. Journal of Management Studies, 40(8), 1919-1941.

Yang, S., Kher, R., \& Newbert, S. L. (2020). What signals matter for social startups? It depends: The influence of gender role congruity on social impact accelerator selection decisions. Journal of Business Venturing, 35(2)

Zimmerman, M. A. (2008). The influence of top management team heterogeneity on the capital raised through an initial public offering. Entrepreneurship Theory and Practice, 32(3), $391-414$. 


\section{Table 1. Selective Correlation Results}

\begin{tabular}{|c|c|c|c|c|c|c|c|c|c|c|c|}
\hline & (1) & & & & & & & & & & \\
\hline selected & 1.00 & & & & & & & & & & \\
\hline model_has_patents & 0.00 & 1.00 & & & & & & & & & \\
\hline entrepreneurialexperience_w & $-0.04^{* * *}$ & $0.07^{* * *}$ & 1.00 & & & & & & & & \\
\hline managerialexperience & $-0.03^{* * *}$ & $0.07^{* * *}$ & $0.30^{* * *}$ & 1.00 & & & & & & & \\
\hline profitability_w & 0.01 & 0.01 & $0.07^{* * *}$ & $0.04^{* * *}$ & 1.00 & & & & & & \\
\hline socialsignals & 0.02 & $0.04^{* * *}$ & $0.03^{* *}$ & 0.01 & $-0.04^{* * *}$ & 1.00 & & & & & \\
\hline economicsignals & $0.06^{* * *}$ & $0.10^{* * *}$ & $0.06^{* * *}$ & $0.09^{* * *}$ & $-0.04^{* * *}$ & 0.01 & 1.00 & & & & \\
\hline selffundedpastyear & $-0.03^{* * *}$ & $0.06^{* * *}$ & $0.09^{* * *}$ & $0.06^{* * *}$ & $0.09^{* * *}$ & $0.06^{* * *}$ & $0.02^{*}$ & 1.00 & & & \\
\hline Country-Birth & $0.07^{* * *}$ & $0.04^{* * *}$ & $-0.02^{*}$ & $-0.05^{* * *}$ & $-0.15^{* * *}$ & $0.08^{* * *}$ & $0.14^{* * *}$ & $-0.06^{* * *}$ & 1.00 & & \\
\hline genderfis 1 & $0.05^{* * *}$ & $-0.07^{* * *}$ & $-0.14^{* * *}$ & $-0.09^{* * *}$ & $-0.03^{* *}$ & $0.07^{* * *}$ & $-0.11^{* * *}$ & $-0.03^{* *}$ & $0.05^{* * *}$ & 1.00 & \\
\hline Education_w & $0.02^{*}$ & $0.06^{* * *}$ & $0.07^{* * *}$ & $0.09^{* * *}$ & $-0.04^{* * *}$ & $0.07^{* * *}$ & $0.11^{* * *}$ & $0.07^{* * *}$ & $-0.03^{* * *}$ & $-0.10^{* * *}$ & 1.00 \\
\hline$N$ & 10298 & & & & & & & & & & \\
\hline
\end{tabular}


Table 2. Regression Analysis Results

\begin{tabular}{|c|c|c|c|c|c|}
\hline VARIABLES & $\begin{array}{c}(1) \\
\text { Model } 1 \\
\end{array}$ & $\begin{array}{c}(2) \\
\text { Model } 2 \\
\end{array}$ & $\begin{array}{c}3) \\
\text { Model } 3 \\
\end{array}$ & $\begin{array}{c}(4) \\
\text { Model } 4 \\
\end{array}$ & $\begin{array}{c}5) \\
\text { Model } 5 \\
\end{array}$ \\
\hline Legal Status For-Profit & $\begin{array}{c}0.0978 \\
(0.0877)\end{array}$ & $\begin{array}{c}0.100 \\
(0.0875)\end{array}$ & $\begin{array}{c}0.122 \\
(0.0881)\end{array}$ & $\begin{array}{c}0.0953 \\
(0.0877)\end{array}$ & $\begin{array}{c}0.122 \\
(0.0881)\end{array}$ \\
\hline Legal Status Non-Profit & $\begin{array}{l}-0.182 \\
(0.128)\end{array}$ & $\begin{array}{l}-0.190 \\
(0.131)\end{array}$ & $\begin{array}{l}-0.181 \\
(0.128)\end{array}$ & $\begin{array}{l}-0.189 \\
(0.128)\end{array}$ & $\begin{array}{l}-0.198 \\
(0.128)\end{array}$ \\
\hline Sector is Health & $\begin{array}{c}0.117 \\
(0.0842)\end{array}$ & $\begin{array}{c}0.103 \\
(0.0846)\end{array}$ & $\begin{array}{c}0.102 \\
(0.0844)\end{array}$ & $\begin{array}{c}0.114 \\
(0.0843)\end{array}$ & $\begin{array}{c}0.0834 \\
(0.0848)\end{array}$ \\
\hline Sector is IT & $\begin{array}{c}0.0257 \\
(0.0944)\end{array}$ & $\begin{array}{c}0.0206 \\
(0.0948)\end{array}$ & $\begin{array}{c}0.0504 \\
(0.0947)\end{array}$ & $\begin{array}{c}0.0253 \\
(0.0943)\end{array}$ & $\begin{array}{c}0.0454 \\
(0.0948)\end{array}$ \\
\hline Sector is Agriculture & $\begin{array}{l}0.0866 \\
(0.100)\end{array}$ & $\begin{array}{c}0.128 \\
(0.1000)\end{array}$ & $\begin{array}{c}0.0793 \\
(0.0997)\end{array}$ & $\begin{array}{l}0.0870 \\
(0.100)\end{array}$ & $\begin{array}{c}0.120 \\
(0.101)\end{array}$ \\
\hline Sector is Other & $\begin{array}{c}0.258 * * * \\
(0.0679)\end{array}$ & $\begin{array}{c}0.248 * * * \\
(0.0683)\end{array}$ & $\begin{array}{c}0.238 * * * \\
(0.0681)\end{array}$ & $\begin{array}{c}0.266 * * * \\
(0.0681)\end{array}$ & $\begin{array}{c}0.240^{* * * *} \\
(0.0683)\end{array}$ \\
\hline Financial Goals & $\begin{array}{c}0.582^{* * *} \\
(0.123)\end{array}$ & $\begin{array}{c}0.573 * * * \\
(0.125)\end{array}$ & $\begin{array}{c}0.580 * * * * \\
(0.124)\end{array}$ & $\begin{array}{c}0.581 * * * \\
(0.123)\end{array}$ & $\begin{array}{c}0.568 * * * \\
(0.124)\end{array}$ \\
\hline Social Motive & $\begin{array}{c}-0.148 \\
(0.0946)\end{array}$ & $\begin{array}{c}-0.149 \\
(0.0947)\end{array}$ & $\begin{array}{l}-0.172^{*} \\
(0.0945)\end{array}$ & $\begin{array}{c}-0.155 \\
(0.0947)\end{array}$ & $\begin{array}{c}-0.184^{*} \\
(0.0952)\end{array}$ \\
\hline Patents & $\begin{array}{l}-0.0354 \\
(0.0747)\end{array}$ & $\begin{array}{c}-0.0538 \\
(0.0750)\end{array}$ & $\begin{array}{l}-0.0187 \\
(0.0748)\end{array}$ & $\begin{array}{l}-0.0421 \\
(0.0747)\end{array}$ & $\begin{array}{c}-0.0466 \\
(0.0755)\end{array}$ \\
\hline Ln(Founder Age) & $\begin{array}{c}0.0879 \\
(0.0986)\end{array}$ & $\begin{array}{c}0.0155 \\
(0.0987)\end{array}$ & $\begin{array}{c}0.0676 \\
(0.0988)\end{array}$ & $\begin{array}{c}0.0878 \\
(0.0987)\end{array}$ & $\begin{array}{c}-0.00546 \\
(0.100)\end{array}$ \\
\hline Entrepreneurial Experience & $\begin{array}{c}-0.0440^{* * * *} \\
(0.0151)\end{array}$ & $\begin{array}{c}-0.0422 * * * \\
(0.0151)\end{array}$ & $\begin{array}{c}-0.0356^{* * *} \\
(0.0151)\end{array}$ & $\begin{array}{c}-0.0454 * * * \\
(0.0151)\end{array}$ & $\begin{array}{c}-0.03511^{* *} \\
(0.0152)\end{array}$ \\
\hline Impact Area Water & $\begin{array}{c}0.115 \\
(0.165)\end{array}$ & $\begin{array}{c}0.159 \\
(0.163)\end{array}$ & $\begin{array}{c}0.156 \\
(0.166)\end{array}$ & $\begin{array}{c}0.116 \\
(0.165)\end{array}$ & $\begin{array}{c}0.204 \\
(0.166)\end{array}$ \\
\hline Impact Area Ag. Prod. & $\begin{array}{l}-0.0231 \\
(0.103)\end{array}$ & $\begin{array}{l}0.0177 \\
(0.102)\end{array}$ & $\begin{array}{l}0.00115 \\
(0.102)\end{array}$ & $\begin{array}{l}-0.0274 \\
(0.103)\end{array}$ & $\begin{array}{l}0.0377 \\
(0.104)\end{array}$ \\
\hline Impact Area Comm. Dev. & $\begin{array}{l}-0.168^{* *} \\
(0.0711)\end{array}$ & $\begin{array}{l}-0.164^{* *} \\
(0.0708)\end{array}$ & $\begin{array}{l}-0.176^{* * *} \\
(0.0713)\end{array}$ & $\begin{array}{l}-0.165^{* *} \\
(0.0712)\end{array}$ & $\begin{array}{l}-0.169 * * \\
(0.0714)\end{array}$ \\
\hline Impact Area Other & $\begin{array}{c}0.0464 \\
(0.0783)\end{array}$ & $\begin{array}{c}0.0257 \\
(0.0786)\end{array}$ & $\begin{array}{c}0.0533 \\
(0.0784)\end{array}$ & $\begin{array}{c}0.0480 \\
(0.0783)\end{array}$ & $\begin{array}{c}0.0346 \\
(0.0787)\end{array}$ \\
\hline Managerial Experience & $\begin{array}{c}-0.155^{* * * *} \\
(0.0538)\end{array}$ & $\begin{array}{l}-0.132 * * \\
(0.0545)\end{array}$ & $\begin{array}{c}-0.142 * * * \\
(0.0539)\end{array}$ & $\begin{array}{c}-0.162 * * * \\
(0.0539)\end{array}$ & $\begin{array}{c}-0.129 * * \\
(0.0545)\end{array}$ \\
\hline Social Signals & $\begin{array}{l}0.240 * * * \\
(0.0553)\end{array}$ & $\begin{array}{l}0.210^{* * * *} \\
(0.0560)\end{array}$ & $\begin{array}{l}0.226 * * * \\
(0.0555)\end{array}$ & $\begin{array}{l}0.233 * * * \\
(0.0555)\end{array}$ & $\begin{array}{l}0.186^{* * * *} \\
(0.0562)\end{array}$ \\
\hline Economic Signals & $\begin{array}{l}0.390^{* * *} \\
(0.0701)\end{array}$ & $\begin{array}{l}0.333^{* * * *} \\
(0.0710)\end{array}$ & $\begin{array}{l}0.423 * * * \\
(0.0705)\end{array}$ & $\begin{array}{l}0.372^{* * *} \\
(0.0707)\end{array}$ & $\begin{array}{l}0.345^{* * *} \\
(0.0724)\end{array}$ \\
\hline Self-Funded Past Year & $\begin{array}{c}-0.176 * * * \\
(0.0504)\end{array}$ & $\begin{array}{c}-0.168 * * * \\
(0.0506)\end{array}$ & $\begin{array}{c}-0.174 * * * \\
(0.0505)\end{array}$ & $\begin{array}{c}-0.182^{* * * *} \\
(0.0507)\end{array}$ & $\begin{array}{c}-0.174 * * * \\
(0.0509)\end{array}$ \\
\hline Profitability & $\begin{array}{l}0.00665 \\
(0.0142)\end{array}$ & $\begin{array}{c}0.0181 \\
(0.0141)\end{array}$ & $\begin{array}{l}0.00626 \\
(0.0142)\end{array}$ & $\begin{array}{l}0.00821 \\
(0.0142)\end{array}$ & $\begin{array}{c}0.0198 \\
(0.0143)\end{array}$ \\
\hline Country-Birth & & $\begin{array}{c}0.109 * * * \\
(0.0181)\end{array}$ & & & $\begin{array}{c}0.108 * * * \\
(0.0174)\end{array}$ \\
\hline Gender (Female $=1$ ) & & & $\begin{array}{c}0.267 * * * \\
(0.0545)\end{array}$ & & $\begin{array}{c}0.276^{* * *} \\
(0.0549)\end{array}$ \\
\hline Education & & & & $\begin{array}{l}0.0119 * * \\
(0.00497)\end{array}$ & $\begin{array}{c}0.0157^{* * * *} \\
(0.00499)\end{array}$ \\
\hline Constant & $\begin{array}{c}-2.122 * * * \\
(0.380)\end{array}$ & $\begin{array}{c}-2.856 * * * \\
(0.398)\end{array}$ & $\begin{array}{c}-2.151 * * * \\
(0.381)\end{array}$ & $\begin{array}{c}-2.260^{* * *} \\
(0.383)\end{array}$ & $\begin{array}{c}-3.061^{* * * *} \\
(0.400)\end{array}$ \\
\hline Observations & 10,298 & 10,298 & 10,298 & 10,298 & 10,298 \\
\hline
\end{tabular}


Figure 1. Selection by Continent

Total Selections of Ventures by Continent

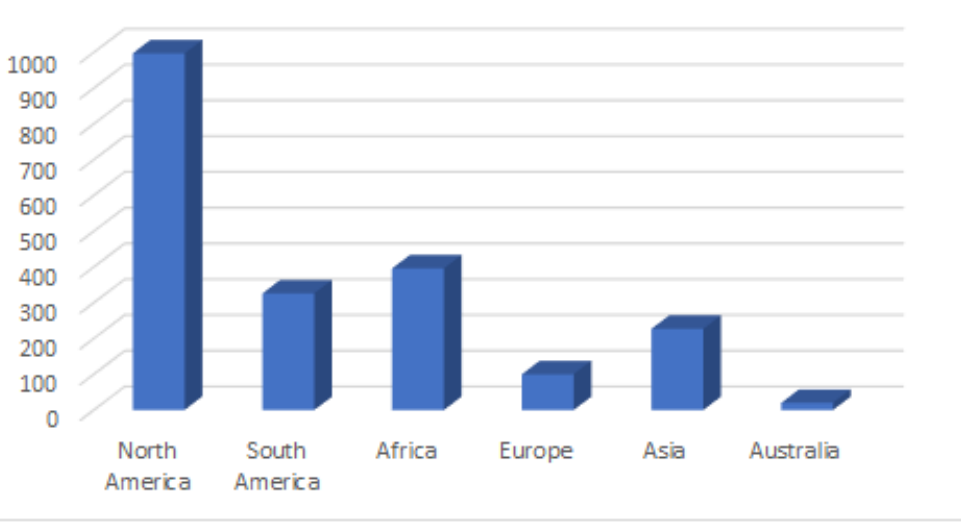

